\title{
PROGRAMY ROZWOJU ŚCIEŻKI KARIERY JAKO KLUCZOWY ELEMENT ZARZĄDZANIA TALENTAMI
}

\author{
Iwona Otola, Agnieszka Raczek \\ Politechnika Częstochowska \\ Wydział Zarządzania
}

\begin{abstract}
Streszczenie: Niniejszy artykuł podejmuje tematykę związaną z zarządzaniem talentami w przedsiębiorstwie. Utalentowani pracownicy są w dzisiejszych czasach kluczowym zasobem dla przedsiębiorstw i często decydują o ich pozycji konkurencyjnej. Warto zatem przyjrzeć się bliżej koncepcji zarządzania talentami. W części praktycznej skupiono się na istocie talentu pracowników oraz podstawowych aspektach zarządzania talentami. Część empiryczna przedstawia studium przypadków dotyczące programów zarządzania talentami w dwóch koncernach międzynarodowych działających na terenie Polski.
\end{abstract}

Słowa kluczowe: programy zarządzania talentami, ścieżka kariery, talent

DOI: $10.17512 /$ znpcz.2016.3.1.14

\section{Wprowadzenie}

Zasoby ludzkie są podstawą każdej organizacji. Nowoczesne praktyki zarządzania wprowadzane przez działy HR w przedsiębiorstwach zwiększają wydajność pracy oraz podnoszą jej jakość. Działania te, mimo iż odnoszą się do zasobów ludzkich, mają na celu usprawnienie funkcjonowania całego przedsiębiorstwa. Coraz częściej mówi się o strategicznym zarządzaniu zasobami ludzkimi. Działalność działów HR nie odnosi się bowiem tylko do zatrudniania, rekrutacji, szkoleń czy też racjonalizacji pracy pod osłoną redukcji lub dopasowania zespołu. Obecnie działania HR nie są mniej ważne niż zarządzanie marketingowe i finansowe organizacji. Przedsiębiorstwa stoją przed nowymi wyzwaniami i aby im sprostać, muszą poszukiwać nowych kompetencji wśród pracowników. Zdolność do przyciągania i rozwijania talentów jest jednym z tych wyzwań.

\section{Pojęcie talentu i zarządzania talentami}

Niepowtarzalność i znaczenie kapitału ludzkiego oraz poszukiwanie źródeł sukcesu zwróciło uwagę badaczy i praktyków na osoby o wybitnym potencjale (ang. high potential ${ }^{1}$ ) i ich kształtowanie na potrzeby organizacji. W ten oto sposób w latach dziewięćdziesiątych XX wieku w USA, wraz ze spopularyzowanym hasłem „wojna o talenty” (ang. the war for talent), zapoczątkowano rozwój niezwykle

\footnotetext{
${ }^{1} \mathrm{~W}$ organizacjach potocznie o talentach mówi się „HiPo”, określa się je także mianem „kluczowych osób", z ang. key people.
} 
istotnego nurtu zarządzania kadrami, jakim jest zarządzanie talentami (ang. talent management) (Listwan (red.) 2010, s. 25). Jak wskazuje A. Suchodolski (2010, s. 215), nowoczesne zarządzanie kadrami dąży do możliwie najpełniejszego wykorzystania potencjału kwalifikacyjnego pracowników i zaspokojenia potrzeb pracowniczych. Ważne jest zatem zidentyfikowanie ambicji zatrudnionych w przedsiębiorstwie pracowników oraz ich możliwości rozwojowych, predyspozycji i potencjału. Pracownik z potencjałem to pracownik, którego wiedza, zdolności, umiejętności oraz predyspozycje osobowościowe mają dla przedsiębiorstwa kluczowe znaczenie, a jego odejście $\mathrm{z}$ organizacji byłoby sporą stratą. Taki pracownik w kontekście rozwoju kariery określany jest mianem talentu. Należy zaznaczyć, że zarówno w teorii, jak i praktyce zarządzania nie ma jednolitej definicji talentu. A. Pocztowski (Pocztowski (red.) 2008, s. 39) wskazuje, że zdefiniowanie talentu w sposób jednoznaczny jest w tej samej mierze ważne, co niezmiernie trudne. Zdaniem autora klasyfikację definicji talentu można oprzeć na następujących kryteriach: wyjątkowości (zakresu) uzdolnień, ich związku z celami (strategią firmy), a także rodzajem uzdolnień. Kryterium wyjątkowości opiera się na założeniu, że talent jest rzadkim dobrem, nie powszechnym, zatem jego podaż i dostępność jest mała. Związek z celami (strategią firmy) oznacza, iż talent jest dobrem lub darem wnoszonym do organizacji niezależnie od potrzeb organizacyjnych i możliwości jego wykorzystania. Kryterium rodzaju uzdolnień pozwala na wyróżnienie osoby mono- i multiuzdolnionej, ponadto podkreśla specyfikę tychże uzdolnień (Pocztowski (red.) 2008, s. 40-41). Zdaniem J.A. Tabor (Tabor 2013, s. 11-12) istniejące definicje rozkładają się na osi $z$ jednej strony obejmującej znaczenia elitarne, uznające za talenty wyłącznie garstkę najlepszych pracowników w przedsiębiorstwie lub też obejmujące kilka wyjątkowych cech (talentów) posiadanych przez danego pracownika, a z drugiej strony definicje egalitarne, czyli uznające za talenty wielu, a w skrajnym przypadku nawet wszystkich zatrudnionych pracowników. Według jednej z najbardziej znanych i prestiżowych firm konsultingowych na świecie - DDI (Development Dimensions International Inc.) pojęcie talentu zostało zdefiniowane jako krytyczny proces misji, który zapewnia organizacjom posiadanie odpowiedniej jakości i ilości osób w celu zaspokojenia obecnych i przyszłych priorytetów biznesowych (Khan, Ayub, Baloch 2013, s. 28-40). S. Steinerowska (Steinerowska 2009) podsumowuje talent jako zasób o ponadprzeciętnych umiejętnościach i zakresie wiedzy, gotowy na nowe wyzwania i zaangażowany w wykonywaną pracę, będący dla każdej organizacji niezbędnym źródłem rozwoju. Tworzy on silne fundamenty walki konkurencyjnej, stanowiąc źródło innowacyjnych i kreatywnych rozwiązań (Puto 2014, s. 94). Talent poszczególnych pracowników stanowi unikalne źródło przewagi konkurencyjnej w szczególności dla przedsiębiorstw międzynarodowych i obecnie dyskurs naukowy w kontekście zarządzania zasobami ludzkimi koncentruje się na pytaniu, w jakim stopniu organizacje efektywnie zarządzają talentami (Collings, Scullion, Morley 2007, s. 198-213.). Zatem, niezależnie od przyjętej definicji talentu, należy określić pakiet różnych, aczkolwiek spójnych działań, umożliwiający przepływ talentu (planowanie ścieżki kariery), czyli zarządzanie talentami. Niewątpliwie nadrzędnym celem zarządzania talentami jest ulokowanie właściwych pracowników na odpowiednich stanowiskach i w odpowiednim czasie, tak aby organizacja mogła 
czerpać korzyści z potencjału i wiedzy pracownika, a on sam realizował swoje ambicje i osiągał satysfakcję z przebiegu kariery zawodowej. Zatem zarządzanie talentami, w przeciwieństwie do talentu per se, dotyczy zestawu procesów odnoszących się do strategicznego zarządzania przepływem talentów przez organizację (Iles, Preece, Chuai 2011, s. 127). R.E. Lewis i R.J. Heckman (Lewis, Heckman 2006, s. 139-140) zauważają, iż pojęcia „zarządzanie talentami” (ang. talent management), „strategia talentów” (ang. talent strategy), „zarządzanie sukcesją” (ang. succession management) i ,planowanie zasobów ludzkich” (ang. human resource planning) są stosowane zamiennie. Autorzy stwierdzają ponadto, że w literaturze przedmiotu można znaleźć w ostatnim czasie artykuły zorientowane na praktykę, opisujące zarządzanie talentami jako sposób myślenia (ang. a mindset), kluczowy składnik efektywnego planowania sukcesji, jak również próbę zapewnienia, aby każdy pracownik w organizacji, na wszystkich poziomach stanowisk, działał na rozwój swojego potencjału. R.E. Lewis i R.J. Heckman (Lewis, Heckman 2006, s. 139-140) przytaczają podejście do zarządzania talentami oparte głównie na koncepcji puli talentów. Zgodnie $\mathrm{z}$ tą koncepcją zarządzanie talentami jest zbiorem procesów mających na celu zapewnienie odpowiedniego przepływu pracowników do pracy w całej organizacji. P. Bohdziewicz (Bohdziewicz 2014, s. 110) wskazuje z kolei, że w wielu organizacjach, szczególnie tych zatrudniających pracowników wiedzy, posiadanie w zasobach kapitału ludzkiego talentów stanowi jeden z najważniejszych atutów konkurencyjności. Należy podkreślić, że w obecnych czasach zarządzanie talentami stanowi wyzwanie dla wszystkich organizacji w kontekście globalizacji, niezależnie od kraju. Ponadto obawy o niedostatek talentów są niemal powszechne. Globalny rynek pracy dla talentów powoduje, że organizacje z całego świata rywalizują o tę samą pulę talentów (Lyria 2013, s. 285).

\section{Koncepcja programów zarządzania talentami}

Praktyczne aspekty zarządzania talentami wciąż są w niewielkim stopniu przedstawione w literaturze przedmiotu. Prowadzone badania dotyczące analizy, które przedsiębiorstwa uwzględniają $\mathrm{w}$ swoich strategiach zarządzanie talentami, wyraźnie wskazują na domenę przedsiębiorstw z kapitałem zagranicznym niż krajowym (Taha, Sirková, Ferencová 2013, s. 24). Ponadto przedsiębiorstwa od zawsze poszukiwały wartościowych pracowników i dbały o nich, ale niekoniecznie wiązało się to $\mathrm{z}$ całym procesem kształtowania ich kariery czy też programem zarządzania talentami. Nawet obecnie większość przedsiębiorstw funkcjonujących na rynku nie ma w swoich strategiach uwzględnionych programów zarządzania talentami. Program zarządzania talentami, jak każdy proces, można zapisać według trzech etapów: wejścia, transformacji i wyjścia (Listwan (red.) 2010, s. 21). Podobne podejście prezentuje K. Huk (Huk 2014, s. 691), stwierdzając, iż programy zarządzania talentami składają się z trzech następujących po sobie etapów:

- I etap: wejście do programu, polegające na identyfikacji i pozyskiwaniu utalentowanych pracowników;

- II etap: funkcjonowanie w programie, w którym następuje rozwój pracowników, tworzenie ich ścieżek kariery, motywowanie; 
- III etap: wyjście z programu, kończące się awansem pracownika bądź powrotem na zajmowane wcześniej stanowisko pracy.

W międzynarodowej literaturze przedmiotu proces ten jest przedstawiany w odniesieniu do czterech aspektów zarządzania talentami proponowanych przez Driesa i Pepermansa (Dries, Pepermans 2008, s. 85-108): identyfikacja talentów, szkolenia i rozwój, planowanie sukcesji oraz zarządzanie retencją pracowników. Zatem proces zarządzania talentami jest oparty na planowaniu strategicznym zasobami ludzkimi, ponieważ główne obszary zainteresowania to rekrutacja, selekcja, szkolenia, rozwój, utrzymanie i związanie z firmą pracowników, ocena i zarządzanie utalentowanymi pracownikami. Sam proces oparty jest często na programach zarządzania talentami, które są związane z modelem planowania kariery i pomagają pracodawcy w ocenie pracowników. Wykorzystanie zbioru różnorodnych praktyk HR ma na celu rozszerzenie u pracowników wiedzy, umiejętności i zdolności. Praktyki te obejmują trening umiejętności zarządzania, rozwiązywanie trudnych zadań, szybkie przekazywanie doświadczeń, rotację pracy, coaching i mentoring (por.: Cichobłaziński 2011, s. 53-63; Dries, Pepermans 2008, s. 85-108). T. Ingram (Ingram 2013, s. 36) spośród kluczowych elementów warunkujących kształt programów zarządzania talentami, takich jak: strategia, struktura, pula kandydatów, wiek i wielkość organizacji, dynamika, złożoność i wrogość otoczenia, mianem jednego z istotniejszych określił kulturę organizacyjną.

To jednak, czy przedsiębiorstwo stosuje programy zarządzania talentami, zależne jest od jego dojrzałości. Zdaniem Tansleya i innych (Tansley i in. 2006, s. 6) zarządzanie talentami związane jest $\mathrm{z}$ dojrzałością przedsiębiorstwa. Cytowani autorzy wyróżniają 5 poziomów dojrzałości organizacji w zarządzaniu talentami, od nieposiadających strategii zarządzania talentami do w pełni zintegrowanego procesu. Przedsiębiorstwa o najniższym poziomie dojrzałości tylko incydentalnie zarządzają talentami, nie mają stworzonych strategii, polityk, a nawet nie mają ustanowionych formalnych praktyk w tym zakresie. Na poziomie drugim wciąż nie można mówić o strategii czy też planie działania na rzecz zarządzania talentami, ale są już wyizolowane pakiety działań. Charakterystyczne dla poziomu trzeciego jest, iż dla wybranych segmentów przedsiębiorstwa stworzone są zintegrowane i skoordynowane działania związane z zarządzaniem talentami. Na poziomie czwartym istnieje już strategia zarządzania talentami, która jest stworzona w taki sposób, aby realizować strategię działu zasobów ludzkich przedsiębiorstwa. Na najwyższym stopniu dojrzałości przedsiębiorstwa zarządzanie talentami ma kluczowe znacznie i skoordynowane jest nie tylko ze strategią działu HR, ale i z ogólną strategią przedsiębiorstwa.

\section{Programy zarządzania talentami w międzynarodowych korporacjach - studium przypadku}

Przedstawione w niniejszym artykule rozważania na temat programów rozwoju ścieżek kariery i zarządzania talentami zostaną uzupełnione o przykłady praktyczne programów funkcjonujących $\mathrm{w}$ dwóch międzynarodowych przedsiębiorstwach produkcyjnych. Porównanie niniejszych programów zawarto w Tabeli 1 . 
Tabela 1. Porównanie programów „Young Talent” i „Create Your Career”

\begin{tabular}{|c|c|c|}
\hline Kryterium & Program ,Young Talent" & Program „Create Your Career” \\
\hline Cel programu & $\begin{array}{l}\text { Pozyskanie osób do objęcia strategicz- } \\
\text { nych stanowisk w ramach koncernu }\end{array}$ & $\begin{array}{l}\text { Wykształcenie odpowiedniej kadry } \\
\text { do objęcia stanowisk kierowniczych } \\
\text { w obszarze produkcyjnym }\end{array}$ \\
\hline Zasięg programu & $\begin{array}{l}\text { Międzynarodowy: obejmuje trzy kraje } \\
\text { europejskie }\end{array}$ & Międzynarodowy: Polska i Czechy \\
\hline $\begin{array}{l}\text { Uczestnik } \\
\text { programu }\end{array}$ & $\begin{array}{l}\text { Pracownik koncernu, w wieku nieprze- } \\
\text { kraczającym } 35 \text { lat }\end{array}$ & Absolwent uczelni technicznych \\
\hline Rodzaj rekrutacji & Wewnętrzna & Zewnętrzna i wewnętrzna \\
\hline $\begin{array}{l}\text { Osoba } \\
\text { odpowiedzialna } \\
\text { za wytypowanie } \\
\text { kandydata }\end{array}$ & Bezpośredni przełożony, sam kandydat & $\begin{array}{l}\text { Nabór prowadzony przez dział HR, } \\
\text { bezpośredni przełożony - } \\
\text { w przypadku rekrutacji wewnętrznej }\end{array}$ \\
\hline Forma rekrutacji & $\begin{array}{l}\text { Wywiad ustrukturalizowany, sesja } \\
\text { Assessment Center }\end{array}$ & $\begin{array}{l}\text { Wywiad ustrukturalizowany, przygo- } \\
\text { towanie pracy na określony temat, } \\
\text { weryfikacja stopnia znajomości } \\
\text { języka angielskiego }\end{array}$ \\
\hline $\begin{array}{l}\text { Czas trwania } \\
\text { programu }\end{array}$ & $1 \mathrm{rok}$ & $\begin{array}{l}\text { Brak ściśle określonych ram czaso- } \\
\text { wych }\end{array}$ \\
\hline $\begin{array}{l}\text { Opiekun } \\
\text { uczestnika }\end{array}$ & $\begin{array}{l}\text { Przydzielony mentor - zazwyczaj osoba } \\
\text { zajmująca wysokie stanowisko w struktu- } \\
\text { rze, wsparcie bezpośredniego przełożo- } \\
\text { nego - sponsora projektu, przełożonego } \\
\text { wyższego szczebla oraz HR }\end{array}$ & $\begin{array}{l}\text { Potencjalny bezpośredni przełożony } \\
\text { uczestnika, HR }\end{array}$ \\
\hline Plan rozwoju & $\begin{array}{l}\text { Precyzyjnie ustalony, indywidualny plan } \\
\text { rozwoju (IPR), konkretne cele do realiza- } \\
\text { cji regularny feedback, sesje mentorin- } \\
\text { gowe, ocena } 360 \text { stopni, konieczność } \\
\text { przygotowania przez uczestnika i prezen- } \\
\text { tacja projektu }\end{array}$ & $\begin{array}{l}\text { Szkolenia praktyczne na potencjal- } \\
\text { nym stanowisku pracy, szkolenia } \\
\text { doskonalące / studia podyplomowe }\end{array}$ \\
\hline Ścieżka kariery & $\begin{array}{l}\text { Po zakończeniu programu uczestnik } \\
\text { trafia do puli talentów, zgodnie } \\
\text { z otrzymanym poziomem oceny jest } \\
\text { monitorowany i typowany do awansu } \\
\text { w przypadku wakatu na istotne w struk- } \\
\text { turze stanowisko }\end{array}$ & $\begin{array}{l}\text { Ustalona, uczestnik obejmuje kon- } \\
\text { kretne stanowisko, niekoniecznie od } \\
\text { razu jest to stanowisko docelowe } \\
\text { wysokiego szczebla }\end{array}$ \\
\hline $\begin{array}{l}\text { Weryfikacja } \\
\text { postępów }\end{array}$ & $\begin{array}{l}\text { W ramach ustalonych sesji, liczne spo- } \\
\text { tkania podsumowujące, sesje mentorin- } \\
\text { gowe, prezentacje, ogromne wsparcie ze } \\
\text { strony osób zarządzających }\end{array}$ & $\begin{array}{l}\text { Na bieżąco weryfikacja dokonywana } \\
\text { przez opiekuna / bezpośredniego } \\
\text { przełożonego }\end{array}$ \\
\hline $\begin{array}{l}\text { Formalizacja } \\
\text { projektu }\end{array}$ & $\begin{array}{l}\text { Duża; z góry ustalony harmonogram } \\
\text { przebiegu programu }\end{array}$ & Mała \\
\hline $\begin{array}{l}\text { Zakończenie } \\
\text { programu }\end{array}$ & $\begin{array}{l}\text { Uroczyste, formalne, na szczeblu mię- } \\
\text { dzynarodowym, stanowiące podsumo- } \\
\text { wanie osiągnięć i procesu rozwoju } \\
\text { uczestnika }\end{array}$ & $\begin{array}{l}\text { Brak formalnego zakończenia pro- } \\
\text { jektu; za zakończenie uznaje się } \\
\text { awans uczestnika }\end{array}$ \\
\hline
\end{tabular}

Źródło: Opracowanie własne 
Oba omawiane programy mają ściśle określony cel oraz przedstawioną ścieżkę kariery dla uczestników. Obejmują one swoim zasięgiem rynek międzynarodowy i są skierowane do osób młodych, przy czym jeden z nich bazuje tylko na zasobach ludzkich wewnętrznych, drugi zaś zezwala na zewnętrzną rekrutację osób. Poniżej zaprezentowano szczegółowe informacje na temat każdego z projektów.

\section{Program „Young Talent”}

Przedsiębiorstwo $\mathrm{X}$ to międzynarodowy koncern, posiadający zakłady zlokalizowane na całym świecie. Tylko w samej Polsce koncern posiada ponad 20 niezależnych spółek produkcyjnych. W przedsiębiorstwie program dotyczący zarządzania talentami funkcjonuje od 2009 roku. W programie biorą udział spółki zlokalizowane w trzech europejskich krajach: Polsce, Rumunii i Bułgarii. Program nosi nazwę „Young Talent” („Młody talent”). Program „Young Talent” ma na celu:

- spełnić rosnące zapotrzebowanie na liderów strategicznych dla przedsiębiorstw wchodzących w skład koncernu, poprzez przyspieszony cykl rozwoju młodych talentów;

- zapewnić przewidywalny i ciągły organizacyjny przepływ talentów;

- przyciągać, rozwijać i utrzymać pracowników z potencjałem;

- sprostać zarządzaniu młodymi talentami i ich wizjom rozwoju kariery z potrzebami biznesowymi organizacji.

Uczestnikiem programu może być tylko i wyłącznie pracownik koncernu, który nie ukończył 35. roku życia. Nabór do programu odbywa się raz w roku. Kandydata zgłasza bezpośredni przełożony lub może się zgłosić także sam kandydat. Następnie kandydatura musi zostać zaakceptowana przez przełożonego wyższego szczebla oraz dział HR. Kandydat do programu winien wykazać się chęcią rozwoju zawodowego, samodzielnością, poszukiwaniem nowych rozwiązań. Szczegółowy przebieg programu został zaprezentowany na Rysunku 1 .

Za realizację celów programu odpowiada zarówno przedsiębiorstwo, jak i sami uczestnicy programu. Przedsiębiorstwo odpowiada za:

- zapewnienie uczestnikom programu ukierunkowanego rozwoju zawodowego,

- monitorowanie procesu,

- zapewnienie przyspieszonych narzędzi do przyspieszonego rozwoju,

- zapewnienie spójności oceny wśród firm uczestniczących w programie. Natomiast uczestnicy programu „Young Talent” odpowiadają za:

- zaprojektowanie i realizację przy wsparciu odpowiednich menedżerów - mentorów działań rozwojowych,

- zaangażowanie w działania na rzecz rozwoju,

- poświęcenie dodatkowego czasu i wysiłku, aby program odniósł sukces. 


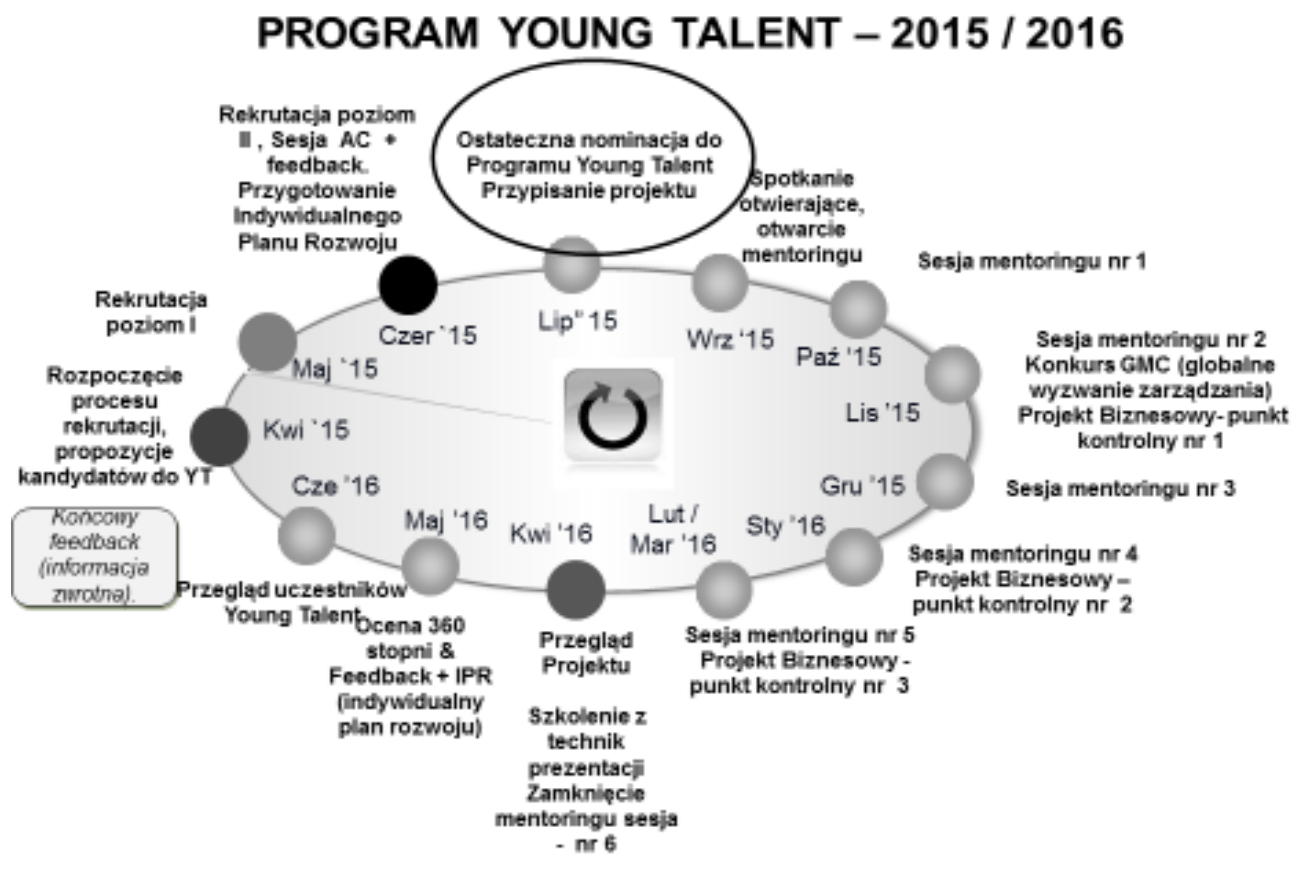

Rysunek 1. Schemat przebiegu programu ,Young Talent” w roku 2015/2016

Źródło: Dane otrzymane z przedsiębiorstwa X

Ważnym aspektem programu, poza samą kwestią rozwoju kompetencji, jest odwiedzanie poszczególnych zakładów wchodzących w skład koncernu, co ma na celu poznawanie specyfiki i różnorodności biznesu oraz ewentualnych problemów związanych $\mathrm{z}$ zarządzaniem przedsiębiorstwem. W ostatniej edycji programu (2014/2015), aż w ponad 80\% przypadków weryfikacja uczestników potwierdziła ich wysoki potencjał (ang. high potencial). U przynajmniej 9\% uczestników potwierdzono cechy przywódcze (ang. leadership), a w latach 2012/2013 miało to miejsce u niemalże 30\% uczestników, ponadto zaobserwowano w kwestii kompetencji poziom ekspercki (ang. expert profile). Dodatkowo warto zauważyć, iż z pierwszej edycji (2009/2010) aż 100\% uczestników otrzymało awans. Na przestrzeni lat 2011-2015 trend ten zdecydowanie uległ obniżeniu. Uczestnikami programu w dużej mierze są mężczyźni. Procentowy udział kobiet nie przekraczał $40 \%$, przy czym dotychczas kobiety - uczestniczki programu występowały tylko w Rumunii i w Bułgarii.

\section{Program „Create Your Career”}

Przedsiębiorstwo Y to kilka przedsiębiorstw wchodzących w skład międzynarodowej grupy kapitałowej - niewątpliwego lidera w swojej branży. Program rozwoju talentów powstał w roku 2012 pod nazwą „Create Your Career” („Stwórz 
swoją karierę"). Projekt ma na celu wykształcenie odpowiedniej kadry, która w przyszłości obejmie kierownicze stanowiska na poszczególnych wydziałach produkcyjnych. Program dedykowany jest do absolwentów uczelni technicznych, którzy swoją przyszłość zawodową wiążą z przemysłem.

\section{Program Create Your Career}
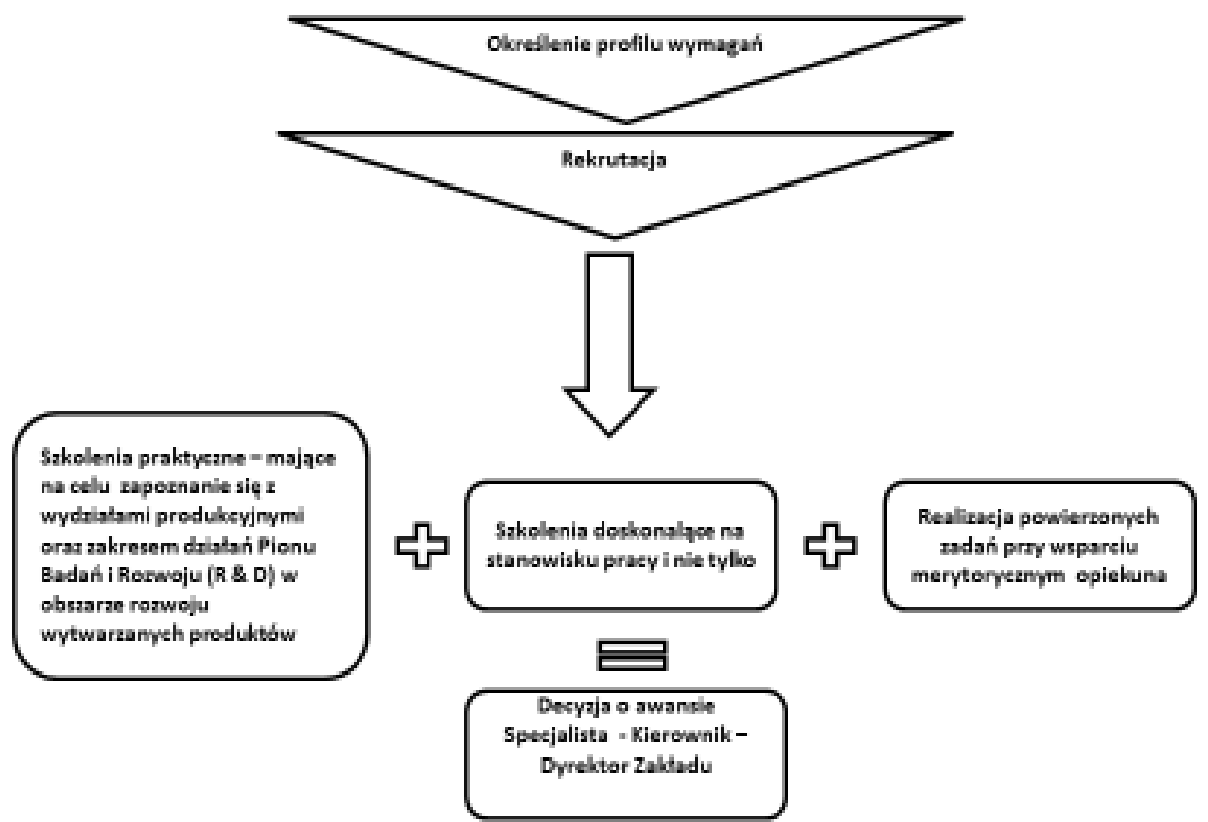

\section{Rysunek 2 . Schemat przebiegu programu „Create Your Career”}

Źródło: Opracowanie własne

Przedsiębiorstwo opracowało zestaw kryteriów i wymagań względem pozyskania idealnych kandydatów - absolwentów:

- ukończenie wydziału chemii lub wydziału związanego z inżynierią produkcji jako warunek konieczny;

- predyspozycje menedżerskie;

- dobra znajomość języka angielskiego;

- zaangażowanie.

Sposób rekrutacji kandydatów do programu prowadzony jest dwutorowo, jako:

- rekrutacja wewnętrzna poprzez: zamieszczanie ogłoszeń na stronie intranetowej, zamieszczanie informacji na tablicach ogłoszeń, bezpośrednie zgłoszenia od przełożonych;

- rekrutacja zewnętrzna poprzez: publikowanie ogłoszeń na portalach rekrutacyjnych, propagowanie programu na targach pracy, propagowanie programu poprzez uczelniane biura karier, poszukiwanie kandydatów spośród laureatów ogólnopolskiego programu „Grasz o staż” oraz praktyki i staże. 
W ramach projektu „Create Your Career” w latach 2012-2016 pozyskano pięciu młodych inżynierów procesu. Przedsiębiorstwo dla talentów proponuje następującą ścieżkę kariery:

- absolwent - inżynier: młodszy inżynier $\rightarrow$ młodszy specjalista ds. technologii $\rightarrow$ specjalista technolog;

- młody inżynier $\rightarrow$ inżynier procesu $\rightarrow$ specjalista ds. technologii $\rightarrow$ starszy specjalista ds. technologii $\rightarrow$ kierownik wydziału;

- stażysta („Grasz o staż”) $\rightarrow$ młodszy specjalista ds. technologii;

- stażysta (płatne praktyki i staże) $\rightarrow$ młodszy inżynier.

Istnieją dwie istotne przesłanki do wdrażania niniejszego projektu w przedsiębiorstwie. Za wartość dodaną projektu uznaje się pozyskanie młodego, kreatywnego pracownika, sukcesora na stanowisko kierownicze w obszarze produkcyjnym oraz możliwość ukształtowania pracownika zgodnie ze strategią i potrzebami firmy. $Z$ całą pewnością wartością dodaną dla przedsiębiorstwa poprzez implementację programów rozwojowych jest kreowanie pozytywnego wizerunku jako pracodawcy, wśród obecnych, jak i przyszłych pracowników. Większość bowiem osób poszukuje pracy, w której może się rozwijać i kształtować swoją karierę zawodową. Ważnym aspektem jest posiadanie bieżącej informacji na temat poziomu wiedzy i kompetencji aktualnie zatrudnionych pracowników. Przedsiębiorstwo wie, jakie kompetencje są w nadwyżce, a jakich pracownikom, zwłaszcza tym kluczowym, brakuje, co należy rozwinąć, jakie nowe umiejętności nabyć, aby zapewnić większy rozwój przedsiębiorstwa i osiągać wyższe zyski z prowadzonej działalności biznesowej.

\section{Podsumowanie}

Podsumowując powyższe rozważania, z całą pewnością należy podkreślić fakt, iż walka o talenty trwa i prawdopodobnie trend ten utrzyma się przynajmniej przez kilka kolejnych lat. Natomiast najważniejszą kwestią jest, aby zarządzanie talentami było naturalnym elementem rozwojowym każdego zaangażowanego pracownika. Każdy bowiem pracownik powinien mieć możliwość ciągłego doskonalenia, rozwoju, realizacji swoich zawodowych aspiracji, bez względu na to, czy w danej organizacji zajmie on $\mathrm{w}$ określonej perspektywie czasu stanowisko wyższe w hierarchii, czy też pozostanie na dotychczasowym. Istotne jest umiejętne wykorzystanie potencjału pracowników wiedzy i zarządzanie ich karierą w taki sposób, aby nie zechcieli opuścić struktur danej organizacji i poszerzyć grona pracowników konkurencji. Programy rozwojowe z całą pewnością stanowią ogromną szansę dla młodych pracowników, wchodzących dopiero na rynek pracy, i warto, aby organizacje takie programy tworzyły i implementowały. Warto też dokonywać systematycznych przeglądów posiadanej w organizacji kadry pracowników, aby nie przeoczyć żadnej osoby zasługującej na miano talentu. Ponadto należy pamiętać, że zanim organizacja zdecyduje się wdrożyć programy rozwojowe i wyłonić grupę talentów, musi mieć jasność w kwestii celu programu (odpowiedzieć na pytanie po co nam ten program), ustalić transparentne dla wszystkich zasady realizacji 
programu, określić jego ramy czasowe, a przede wszystkim mieć pomysł, co zrobić z talentami po ukończeniu przez uczestnika programu (mamy talent i co dalej?). Najgorsze, a niestety dość często występujące w organizacjach, to wyłonienie osób z potencjałem, zaproszenie ich do udziału w rozmaitych projektach szkoleniowych, sesjach development center, sesjach coachingowych i mentorskich, przedstawienie wizji wspaniałej ścieżki kariery, a potem zaniechanie dalszych działań. Wówczas zamiast zmotywowanego talentu mamy rozczarowanego pracownika, który wzbogacony o nowo zdobytą wiedzę i umiejętności, prawdopodobnie zacznie poszukiwać wyzwań zawodowych, ale już w innej organizacji.

\section{Literatura}

1. Bohdziewicz P. (2014), Wspótczesne przeobrażenia psychologicznego kontraktu zatrudnienia i ich konsekwencje jako wyzwanie dla zarzadzania zasobami ludzkimi, [w:] Antczak Z., Borkowska S. (red.), Przyszłość zarządzania zasobami ludzkimi. Dylematy i wyzwania, Difin, Warszawa.

2. Cichobłaziński L. (2011), Zarządzanie karierami pracowniczymi a rozwój kapitału ludzkiego w organizacji, „Gospodarka i Finanse”, Vol. 1.

3. Collings D.G., Scullion H., Morley M.J. (2007), Changing Patterns of Global Staffing in the Multinational Enterprise: Challenges to the Conventional Expatriate Assignment and Emerging Alternatives, ,Journal of World Business”, Vol. 42(2).

4. Dries N., Pepermans R. (2008), Real' High-Potential Careers: An Empirical Study into The Perspectives of Organisations and High Potentials, „Personnel Review”, Vol. 37.

5. Huk K. (2014), Rozwój utalentowanych pracowników w ramach programów zarzadzania talentami w świetle badań, „Prace Naukowe Uniwersytetu Ekonomicznego we Wrocławiu”, nr 340.

6. Iles P., Preece D., Chuai X. (2011), Talent Management as a Management Fashion in HRD: Towards a Research Agenda, „Human Resource Development International”, Vol. 13(2).

7. Ingram T. (2013), Pomiar kultury organizacyjnej jako determinanty programów zarządzania talentami, „Nauki o Zarządzaniu”, nr 3(16).

8. Khan M.Z.A., Ayub A., Baloch Q.B. (2013), Importance of Talent Management in Business Strategy: A Critical Literature Review, „Abasyn University Journal of Social Sciences”, Vol. 6(1).

9. Lewis R.E., Heckman R.J. (2006), Talent Management: A Critical View, „Human Resource Management Review", Vol. 16.

10. Listwan T. (red.) (2010), Zarzadzanie kadrami, C.H. Beck, Warszawa.

11. Lyria R.K. (2013), Role of Talent Management on Organization Performance in Companies Listed in Nairobi Security Exchange in Kenya: Literature Review, „International Journal of Humanities and Social Science", Vol. 3, No. 21.

12. Pocztowski A. (red.) (2008), Zarządzanie talentami w organizacji, Wolters Kluwer, Kraków.

13. Puto A. (2014), Concept of Talent Management as a Stimulant for the Development of an Enterprise, [w:] Seroka-Stolka O. (red.), Wspótczesne koncepcje zarządzania przedsiębiorstwem, Sekcja Wydawnictw Wydziału Zarządzania Politechniki Częstochowskiej, Częstochowa.

14. Steinerowska S. (2009), Zarzadzanie talentami jako czynnik sukcesu organizacji XXI wieku, http://www.konferencja.edu.pl/Files/ConfXV/Reports/PDF/Steinerowska\%20Sylwia\%20$\% 20$ Zarzadzanie $\% 20$ talentami\%20jako\%20czynnik\%20sukcesu\%20organizacji\%20XXI\%2 0wieku.pdf (dostęp: 15.05.2016).

15. Suchodolski A. (2010), Rozwój i zarządzanie kariera pracowników, [w:] Listwan T. (red.), Zarzadzanie kadrami, C.H. Beck, Warszawa. 
16. Tabor J.A. (2013), Zarzadzanie talentami w przedsiębiorstwie. Koncepcje, strategie, prakty$k a$, Poltext, Warszawa.

17. Taha V.A., Sirková M., Ferencová M. (2013), Selected Practices of Talent Management: Insight into Slovak Organizations „Polish Journal of Management Studies”, Vol. 8.

18. Tansley C., Harris L., Stewart J., Turner P. (2006), Talent Management: Understanding the Dimensions, Change Agenda, CIPD, London.

\section{CAREER PATH DEVELOPMENT PROGRAMMES AS A KEY ELEMENT OF TALENT MANAGEMENT}

Abstract: This article takes topics related to talent management in the enterprise. Talented employees are nowadays a key resource for businesses and often decide on competitive position of the enterprises. It is therefore worth a closer look at the concept of talent management. The theoretical part of the article focuses on the essence of the talent of employees and basic aspects of talent management. The empirical part presents case studies on talent management programs in two international corporations operating on Polish market.

Keywords: talent management programs, career path, talent 